\title{
CITRA TUBUH, DUKUNGAN SOSIAL TEMAN SEBAYA, DAN PENERIMAAN DIRI PADA ORANG DENGAN OBESITAS (ODO)
}

\author{
Novi Nindy Elisa ${ }^{1}$, Lina Nur Elfiana ${ }^{2}$, Delvina Alifah Rahma ${ }^{3}$, dan Abdul Muhid ${ }^{4}$ \\ ${ }^{1,2,3,4}$ Prodi Psikologi, Fakultas Psikologi dan Kesehatan, UIN Sunan Ampel Surabaya \\ Jl. Ahmad Yani 117 Surabaya
}

Email: abdulmuhid@uinsby.ac.id, novielisa19@gmail.com

\begin{abstract}
Abstrak
Penelitian dilakukan untuk menguji hubungan antara citra tubuh dan dukungan sosial teman sebaya terhadap penerimaan diri pada orang dengan obesitas. Metode dalam penelitian ini adalah metode kuantitatif korelasional. Jumlah sampel sebanyak 100 subjek dengan kriteria Orang Dengan Obesitas (ODO) yang berusia 18-40 tahun, diambil menggunakan teknik purposive sampling. Pengumpulan data menggunakan instrumen angket tertutup. Analisis data pada penelitian ini menggunakan uji regresi berganda. Hasil penelitian ini menunjukkan besar koefisien korelasi pada variabel citra tubuh adalah 0,289 dengan nilai $p$ 0,002, dan pada variabel dukungan sosial teman sebaya adalah 0,321 dengan $p$ 0,001. Selain itu, diperoleh nilai $F$ sebesar 11,039 dengan signifikansi $p<0,000$. Sehingga dapat disimpulkan ada hubungan yang positif dan signifikan antara citra tubuh dan dukungan sosial teman sebaya terhadap penerimaan diri pada Orang Dengan Obesitas (ODO). Pengaruh citra tubuh dan dukungan sosial teman sebaya dalam penelitian ini sebesar $18,5 \%$.
\end{abstract}

Kata kunci: Citra tubuh, Dukungan Sosial Teman Sebaya, Penerimaan Diri

\section{BODY IMAGE, PEER SOCIAL SUPPORT, AND SELF-ACCEPTANCE IN PEOPLE WITH OBESITY (ODO)}

\begin{abstract}
The study was conducted to examine the relationship between body image and peer social support on selfacceptance in obese people. The method in this research is correlational quantitative method. The number of samples was 100 subjects with the criteria of People with Obesity (ODO) aged 18-40 years, taken using purposive sampling technique. Data collection using a closed questionnaire instrument. Analysis of the data in this study using multiple regression test. The results of this study indicate that the correlation coefficient on the body image variable is 0.289 with a $p$ value of 0.002 , and the peer social support variable is 0.321 with a $p$ value of 0.001 . In addition, the $F$ value of 11.039 was obtained with a significance of $p<0.000$. So it can be concluded that there is a positive and significant relationship between body image and peer social support on selfacceptance in people with obesity (ODO). The effect of body image and peer social support in this study was $18.5 \%$.
\end{abstract}

Keywords: Body Image, Peer Social Support, Self-acceptance

\section{Pendahuluan}

Di kehidupan bermasyarakat, sering kali kita mendengar orang mengatakan "gemuk tanda bahagia". Tetapi, perlu diketahui bahwa orang yang berlebihan berat badan juga tidak baik dan berisiko. Kelebihan berat badan ini disebut juga obesitas. Obesitas adalah salah satu kelainan metabolisme yang disebabkan oleh pengongsumsian makanan jauh melebihi kebutuhan, sehingga energi masuk dan keluar menjadi tidak seimbang. (Andarbeni \& Probosari, 2019; Sawitri dkk., 2019). 
Pada tahun 2008, orang dengan obesitas berjumlah sekitar 300 juta orang, sementara kasus kematian yang disebabkan oleh obesitas berjumlah sekitar 2,8 juta orang (Widianti \& Tafal, 2014). Seperti halnya diabetes (44\%), kanker (41\%), penyakit jantung (23\%) dan obesitas menjadi penunjang utama dari penyakit degeneratif (Gibney, 2008). Salah satu permasalahan gizi di Indonesia adalah obesitas. Hasil penelitian Kesehatan Dasar pada 2017 menunjukkan populasi obesitas sebesar 11,7\% pada penduduk dewasa usia 18 tahun ke atas, sedangkan menilai dari jenis kelamin, perempuan sebesar 15,5\% dan laki-laki sebesar 7,8\% (Kementerian Kesehatan Republik Indonesia, 2008).

Seseorang dikatakan obesitas apabila memiliki Indeks Massa Tubuh (IMT) yang tidak seimbang. WHO menetapkan IMT sebagai tolak ukur yang membandingkan antara berat badan dengan tinggi badan seseorang. Untuk menentukan IMT, berat dan tinggi badan seseorang diukur secara terpisah, kemudian nilainya dibagi sehingga didapat nilai IMT dalam satuan $\mathrm{kg} / \mathrm{m}^{2}$ (Situmorang, 2015). WHO Western Pasific Region (2000) mengklasifikasikan IMT orang dengan obesitas menjadi dua, yaitu Obesitas I dan Obesitas II. Orang dengan obesitas I memilki IMT sebesar $25-29,9 \mathrm{~kg} / \mathrm{m}^{2}$ dan orang dengan obesitas II memiliki IMT sebesar $\geq 30 \mathrm{~kg} / \mathrm{m}^{2}$. Sedangkan, secara nasional, seseorang dikatakan obesitas apabila memiliki IMT sebesar 25,1-27,0 $>27 \mathrm{~kg} / \mathrm{m} 2$ (P2PTM, 2018).

Berdasarkan penelitian sebelumnya, ditemukan hasil bahwa keluarga miskin yang mengalami obesitas sebanyak $22,4 \%$. Dimana sebanyak $88,25 \%$ berjenis kelamin perempuan dan berusia lebih dari 25 tahun (Nadimin et al., 2015). Penelitian lain yang mengukur lingkar pinggang pada populasi sebanyak 966 orang, menyatakan bahwa sebanyak 220 orang alami obesitas dengan presentase $22,8 \%, 59$ orang diantaranya berjenis kelamin laki-laki $(6,1 \%)$ dan 161 orang perempuan $(16,7 \%)$ (Hendra et al., 2016).

Meningkatnya resiko penyakit tidak menular sampai produktifitas yang menurun merupakan dampak yang ditimbulkan dari obesitas (Safitri \& Rahayu, 2020). Orang dengan obesitas rentan penyakit tidak menular, seperti peningkatan kadar kolesterol, hipertensi, resistensi insulin, kanker, kehamilan yang beresiko, serangan jantung, penuaan otak, penurunan kualitas sperma, stroke, dan rendahnya kadar vitamin D dalam tubuh (Sawitri dkk., 2019; Sundari, 2018). Orang dengan obesitas juga mudah lelah/mengantuk dan kesulitan keseimbangan (Fernando, 2019).

Banyaknya penelitian yang membahas risiko dan dampak negatif pada orang dengan obesitas dapat mengakibatkan orang dengan obesitas merasa terjebak dalam penilaian terhadap penerimaan dirinya sendiri. Penerimaan diri berkaitan dengan bagaimana seseorang bersikap dalam mau menerima dirinya sendiri, yang ditandai dengan merasa lega terhadap dirinya sendiri, baik itu meliputi bakat yang dimiliki, kualitas dalam dirinya, dan mau mengakui jika dirinya hanyalah makhluk yang mempunyai batasan (Hasmalawati, 2017). Penerimaan diri tidak lepas dari penerimaan individu terhadap kondisi fisik yang dimilikinya. Penerimaan diri dianggap penting untuk kesehatan mental seseorang, karena dengan adanya sikap ini, seseorang dapat terhindar dari berbagai kesulitan emosional termasuk dapat berpikir rasional mengenai positif negatifnya masalah yang terjadi tanpa memunculkan perasaan yang buruk, menimbulkan rasa rendah diri, pertikaian, dan perasaan kurang aman (Hasmalawati, 2017; Ridha, 2012). Ada keterkaitan yang erat antara penerimaan diri dengan penerimaan pada kondisi fisik yang dimiliki oleh individu. Allport dalam Sarwono (2011) menyatakan bahwa seseorang yang mau menerima dirinya memiliki ciri-ciri diantaranya mempunyai persepsi yang positif tentang dirinya, bisa mengatur dan memahami kemarahan dan rasa frustasinya, mampu 
menerima kritik seseorang dengan lapang dada, juga mampu mengkontrol emosi baik itu depresi atau kemarahan.

Penerimaan diri pada orang dengan obesitas dipengaruhi oleh 2 faktor yaitu internal dan eksternal. Faktor internal seperti sikap food concern, self-efficacy, citra tubuh, serta karakteristik individu (tingkat pendidikannya, status pernikahan, kondisi sosial ekonominya, penyakit yang tidak menular serta riwayat melahirkan). Sedangkan faktor eksternalnya terdiri dari dukungan keluarga dan lingkungan sekitarnya (Safitri \& Rahayu, 2020). Selain itu, obesitas sangat dipengaruhi oleh pola makan dengan presentase $98 \%$, lalu genetik (76\%), aktivitas fisik, pola hidup, dan faktor lingkungan (24\%), serta faktor kesehatan dan psikis (stres dan kekecewaan) sebesar 14\% (Hendra dkk., 2016).

Citra tubuh yang negatif adalah salah satu faktor yang mengakibatkan seseorang memiliki penerimaan diri yang rendah. Citra tubuh adalah persepsi tentang penampilan diri sendiri di hadapan orang lain (Fernando, 2019). Berdasarkan penelitian yang sudah dilakukan Fernando (Fernando, 2019), menunjukkan bahwa orang dengan obesitas memiliki citra tubuh yang menganggap fisiknya tidak menarik dan kesulitan menyesuaikan diri, sehingga orang dengan obesitas merasa rendah dan menarik diri dari lingkungannya (Fernando, 2019). Sebaliknya, citra tubuh yang positif membuat orang dengan obesitas tanpa merasa rendah diri serta mampu menerima kekurangan dan kelebihan dirinya (Hasmalawati, 2017).

Seorang individu akan merasa diperhatikan, bernilai dan dicintai melalui dukungan sosial yang diberikan oleh teman sebaya. Dikutip dari Vizza dan Ningsih (2019), Solomon (2004) menyatakan bahwa ketika individu memberi rasa empati, dukungan, kasih sayang sperti persahabatan, serta beberapa bantuan yang bisa mengusir rasa frustasi, sepi, dan juga penolakan dari orang lain. Vizza dan Ningsih (2019) dalam penelitiannya menjelaskan bahwa tingginya dukungan teman sebaya yang diperoleh mampu membuat penerimaan diri individu menjadi semakin baik. Oleh karenanya, orang dengan obesitas jelas sanggat memerlukan dukungan sosial teman sebaya agar penerimaan dirinya semakin baik.

Sehingga dari berbagai uraian di atas, tujuan dari penelitian ini untuk mengetahui Hubungan Citra Tubuh dan Dukungan Sosial Teman Sebaya terhadap Penerimaan Diri pada Orang dengan Obesitas (ODO).

\section{Metode}

Penelitian ini menggunakan metode kuantitatif korelasional. Untuk memperoleh data penelitian, instrumen yang digunakan adalah angket tertutup, yang mana peneliti telah menentukan pertanyaan beserta pilihan jawabannya. Data diperoleh secara langsung melalui angket sehingga data pada penelitian ini merupakan data primer. Penelitian ini menggunakan model skala likert. Populasi pada penelitian ini adalah Orang dengan Obesitas (ODO) secara umum. Sampel diambil menggunakan teknik purposive sampling, di mana subjek penelitian disesuaikan dengan kriteria penelitian yaitu Orang Dengan Obesitas (ODO) dan berusia 18 - 40 tahun. Hasil penyebaran angket kepada subjek penelitian melalui Google Form melalui media sosial dalam kurun waktu 2 minggu diperoleh sebanyak 100 responden dengan jenis kelamin laki-laki sebanyak 25 orang dan perempuan sebanyak 75 orang. Responden dengan Indeks masa tubuh (IMT) antara $25.1-27 \mathrm{~kg} / \mathrm{m}^{2}$ sebanyak 41 orang dan IMT $>27 \mathrm{~kg} / \mathrm{m}^{2}$ sebanyak 59 orang.

Adapun alat ukur psikologi yang digunakan pada penelitian ini adalah 3 skala psikologis diantaranya (1) Skala Penerimaan Diri, terdapat 4 indikator yang diukur yaitu memiliki gambaran 
yang positif tentang diri, mampu mengatur dan bertoleransi terhadap rasa frustasi dan kemarahan, mampu berinteraksi tanpa memusuhi mereka apabila kritik disampaikan pada diri mereka, serta mampu mengatur keadaan emosi mereka (Heriyadi, 2013). Skala ini terdiri atas 12 item dengan nilai reliabilitas yang tinggi $(a=0,77)$ dan memiliki nilai validitas dengan rentang $0,371-0,707$. Contoh salah satu item pada skala ini adalah "Saya menyadari kekurangan dalam diri tanpa melupakan kelebihan yang saya miliki". (2) Skala Citra tubuh, terdiri dari 3 aspek yaitu kognitif (persepsi, pemikiran, kepercayaan), perasaan, dan perilaku (Cash, 2003). Skala ini terdiri dari 10 item dengan reliabilitas yang cukup $(a=0,475)$ dan memiliki nilai validitas dalam rentang $0,508-0,828$. Contoh salah satu item pada skala ini adalah "Saya merasa puas dengan tubuh yang saya miliki saat ini". (3) Skala Dukungan Teman Sebaya, terdapat 3 aspek yang diukur yaitu dukungan emosional, dukungan konkret, dan dukungan informasi (Corcoran dan Robert, 2015). Skala ini terdiri dari 10 item dengan reliabilitas yang tinggi $(a=0,87)$ dan validitas yang berkisar antara $0,589-0,811$. Contoh salah satu item pada skala ini adalah "Teman saya selalu memotivasi saya saat saya sedang down". Seluruh data dianalisis menggunakan uji regresi berganda, dengan bantuan SPSS Program for Windows Versi 24.

\section{Hasil}

Berdasarkan kriteria subjek penelitian yang telah ditentukan, diperoleh 100 responden yang menjadi sampel penelitian sebagai berikut.

Tabel 1. Data Demografi

\begin{tabular}{lll}
\hline Demografi & Jumlah & Presentase \\
\hline Jenis Kelamin & & \\
Laki-laki & 25 & $25 \%$ \\
Perempuan & 75 & $75 \%$ \\
Indeks Massa Tubuh (IMT) & & \\
$25,1-27,0 \mathrm{~kg} / \mathrm{m}^{2}$ & 41 & $41 \%$ \\
$>27,0 \mathrm{~kg} / \mathrm{m}^{2}$ & 59 & $59 \%$ \\
Usia & & \\
$18-20$ Tahun & 52 & $52 \%$ \\
$21-25$ Tahun & 43 & $43 \%$ \\
$26-30$ Tahun & 4 & $4 \%$ \\
$31-35$ Tahun & 1 & $1 \%$ \\
$36-40$ Tahun & 0 & $0 \%$ \\
\hline
\end{tabular}

Tabel 1 mengungkapkan data demografi pada subjek penelitian ini. Dapat diketahui, jumlah laki-laki sebanyak 25 orang dengan presentase $25 \%$, dan perempuan sebanyak 75 orang dengan presentase $75 \%$. Kemudian dilihat dari besar nilai IMT, mayoritas subjek berada pada tingkat berat (lebih dari $27,0 \mathrm{~kg} / \mathrm{m}^{2}$ ) yaitu sebanyak 59 orang dengan presentase (59\%). Selanjutnya, pada kategori usia, mayoritas subjek berusia 18-20 tahun sebanyak 52 orang dengan presentase $52 \%$ dan paling sedikit berusia 31-35 tahun sebanyak 1 orang (1\%). Tidak ditemukan subjek berusia 36-40 tahun.

Pada penelitian ini, analisis deskriptif data mencakup skor empirik dan skor hipotetik. Skor empirik didapat dari skala penerimaan diri yang digunakan dalam penelitian ini, yaitu sebanyak 12 item disertai empat pilihan jawaban. Nilai maksimum dan minimumnya adalah $12 \times 1$ hingga $12 \times 4$, yaitu 12 hingga 48 dengan mean hipotetik sebesar $(12+48): 2=30$. Untuk standar deviasi hipotetik 
didapat sebesar $(48-12): 6=10$. Berikut ini adalah tabel perbandingan antara data empirik dan hipotetik variabel penerimaan diri.

Tabel 2. Perbandingan Data Empirik dan Hipotetik Penerimaan Diri

\begin{tabular}{|c|c|c|c|c|c|c|c|c|}
\hline \multirow{2}{*}{ Variabel } & \multicolumn{3}{|c|}{ Empirik } & \multirow{2}{*}{ SD } & \multicolumn{3}{|c|}{ Hipotetik } & \multirow{2}{*}{ SD } \\
\hline & Min & Max & Mean & & Min & Max & Mean & \\
\hline $\begin{array}{c}\text { Penerimaan } \\
\text { Diri }\end{array}$ & 18 & 47 & 32,5 & 4,83 & 12 & 48 & 30 & 10 \\
\hline
\end{tabular}

Berdasarkan tabel perbandingan data deskriptif di atas, diketahui bahwa nilai mean empirik $(32,5)$ lebih besar dari mean hipotetik $(30)$ atau $32,5>30$, sehingga dapat disimpulkan bahwa pada subjek penelitian ini, penerimaan diri mereka lebih tinggi dibandingkan populasi pada umumnya.

Berikutnya, subjek penelitian digolongkan ke dalam 3 kategorisasi penerimaan diri, yaitu kategori rendah, sedang, dan tinggi.

Tabel 3. Kategorisasi Data Penerimaan Diri

\begin{tabular}{ccccc}
\hline Variabel & Rentang Nilai & Kategori & Jumlah $(\mathbf{n})$ & Persentase \\
\hline \multirow{3}{*}{ Penerimaan Diri } & $x<28$ & Rendah & 8 & $8 \%$ \\
& $28 \leq x<37$ & Sedang & 60 & $60 \%$ \\
& $x \geq 37$ & Tinggi & 32 & $32 \%$ \\
\hline
\end{tabular}

Dari tabel 3 di atas, disimpulkan bahwa secara keseluruhan, penerimaan diri pada subjek penelitian ini berada dalam kategori sedang.

Tabel 4. Hasil Uji Regresi Linier Berganda

\begin{tabular}{cccc}
\hline Variabel & Nilai Sig. & Harga Koefisien & Taraf Sig. \\
\hline Citra tubuh & 0,002 & 0,289 & 0,005 \\
$\begin{array}{c}\text { Dukungan Sosial Teman } \\
\text { Sebaya }\end{array}$ & 0,001 & 0,321 & 0,005 \\
\hline
\end{tabular}

Untuk melihat hubungan citra tubuh dan dukungan sosial teman sebaya terhadap penerimaan diri, data dianalisis menggunakan regresi linier berganda. Hasilnya pada tabel 4 di atas menunjukkan besar koefisien korelasi pada variabel citra tubuh adalah 0,289 dengan nilai sig. 0,002, yang mana dapat diartikan bahwa ada korelasi antara citra tubuh dengan penerimaan diri pada Orang dengan Obesitas (ODO). Hasil uji hipotesis berikutnya menunjukkan besar koefisien korelasi pada variabel dukungan sosial teman sebaya adalah 0,321 dengan sig. 0,001<0,005, yang mana artinya antara dukungan sosial teman sebaya dengan penerimaan diri pada Orang dengan Obesitas (ODO) terdapat hubungan yang signifikan. 
Tabel 5. Hasil Uji Regresi Ganda

\begin{tabular}{llccccc}
\hline Model & Sum of Squares & df & Mean Square & F & Sig. \\
\hline 1 & Regression & 421,781 & 2 & 210,890 & 11,039 & $.000^{b}$ \\
& Residual & 1853,059 & 97 & 19,104 & & \\
\cline { 2 - 7 } & Total & 2274,840 & 99 & & & \\
\hline
\end{tabular}

Berdasarkan tabel 5 , hasil pengolahan data dengan regresi berganda menghasilkan nilai $\mathrm{F}$ sebesar 11,039 dengan signifikansi 0,000 ( $<<0,05)$, yang mana menunjukkan bahwa variabel citra tubuh dan variabel dukungan sosial teman sebaya bersama-sama mempengaruhi variabel penerimaan dini. Dengan kata lain, terdapat hubungan yang signifikan antara citra tubuh dan dukungan sosial teman sebaya terhadap penerimaan diri pada Orang Dengan Obesitas (ODO).

Tabel 6. Koefisien Determinan

\begin{tabular}{cccc}
\hline \multicolumn{4}{c}{ Model Summary } \\
\hline $\mathbf{R}$ & $\mathbf{R}$ Square & Adjusted R Squre & Sig. F Change \\
.431 & 0,185 & 0,169 & 0,000 \\
\hline
\end{tabular}

Berdasarkan tabel 6, diketahui bahwa nilai Sig. F Change sebesar 0,000. Nilai Sig. F Change lebih kecil dari nilai probabilitas 0,05 atau 0,000 $<0,05$, sehingga dapat disimpulkan bahwa variabel citra tubuh dan variabel dukungan sosial teman sebaya secara simultan berhubungan dengan variabel penerimaan diri. Adapun koefisien korelasinya ( $R$ ) sebesar 0,431 dan nilai koefisien determinasinya (R Square) sebesar 0,185 yang berarti $18,5 \%$ variabel penerimaan diri dipengaruhi oleh variabel citra tubuh dan dukungan sosial teman sebaya, sementara sisanya sebesar $81,5 \%$ dipengaruhi oleh variabel lain yang tidak diteliti dalam penelitian ini.

\section{Pembahasan}

Hasil uji statistik menunjukkan ada hubungan yang positif dan signifikan antara citra tubuh dan dukungan sosial teman sebaya terhadap penerimaan diri pada ODO. Penerimaan diri adalah ketika seseorang menganggap dirinya berharga dan peduli pada dirinya. (Supratiknya, 1995). Tingkat dimana seseorang sangat mempertimbangkan kepribadiannya dan bersedia hidup berdampingan dengan kepribadian tersebut maka hal itu disebut penerimaan diri (Hurlock, 1999). penerimaan diri adalah merasa lega terhadap dirinya sendiri, bakatnya, kualitas yang dimiliki dan mau mengakui jika dirinya mempunyai keterbatasan (Chaplin, 2006). Handayani dkk (1998) bahwa sejauh mana individu mampu mengakui dan menyadari kepribadiannya serta digunakan dalam kehidupan sehari-hari disebut penerimaan diri

Penelitian ini menunjukkan semakin positif persepsi seseorang tentang citra tubuhnya maka semakin baik pula penerimaan dirinya. Sebaliknya, semakin buruk persepsi seseorang tentang citra tubuhnya maka semakin buruk penerimaan dirinya. Hasil penelitian ini mendukung penelitian terdahulu bahwa ada hubungan yang signifikan antara citra tubuh dan penerimaan diri (Silalahi \& Patriona, 2018). Penelitian lainnya juga membuktikan bahwa citra tubuh mempunyai hubungan yang positif terhadap penerimaan diri (Maryam \& Ifdil, 2019). Citra tubuh adalah persepsi individu tentang bentuk tubuhnya, daya tariknya, batasan tubuhnya, dan perasaan mengenai bentuk tubuh yang dimiliki (Grogan, 2016). Citra tubuh adalah penilaian mengenai diri sendiri serta perilaku yang timbul terhadap kondisi fisik individu (Cash, 2004). Citra tubuh adalah perasaan individu mengenai penampilannya (Aquino et al., 2009) 
Menurut Cash (2004), terdapat 2 hal yang melekat pada individu mengenai penilaian dan perilakunya terhadap citra tubuh yang dimiliki. Ada 4 hal, yaitu: (a) Pikiran, dalam pikiran individu pasti mempunyai standar tentang penampilan dari segi fisik. Standar ini bisa memberi pengaruh terhadap persepsi tentang bentuk tubuh yang dimiliki (Heatherton, 1993). (b) Rasa Percaya (beliefs), kepercayaan berpengaruh terhadap perasaan dan perspektif wanita tentang tubuhnya. Wanita akan mudah menyesuaikan diri terhadap bentuk tubuhnya jika mempunyai rasa percaya diri. Sebaliknya, Wanita yang menilai bahwa pandangan orang lain itu penting bagi dirinya maka dia akan selalu menilai negative bentuk tubuhnya dan kurang menerima dirinya sendiri (Brennan dkk, 2010). (c) Perasaan (feelings), bagian dan ukuran tubuh akan memunculkan perasaan positif atau perasaan negative selain itu juga akan memunculkan rasa puas dan tidak puas. (d) Perilaku (behaviors), persepsi dan perasaan seseorang mengenai bentuk tubuh akan menimbulkan perilaku tertentu. Memakai pakaian tertentu, marah saat berfikir dan melihat penampilannya, menutupi serta mengubah bentuk tubuh akan dilakukan oleh wanita ketika dia merasa kurang puas pada tubuhnya (Sarwer dkk., 2005). Menurut (Grogan, 2016) saat wanita kurang puas dengan penampilannya maka ia akan mencoba diet, tidak mengekspose tubuhnya dan mencoba melakukan oprasi plastic.

Hubungan yang positif dan signifikan juga ditunjukkan oleh dukungan sosial teman sebaya terhadap penerimaan diri. Sarason menyatakan bahwa kepedulian, keberadaan, kesediaan, menghargai dan menyayangi yang dilakukan oleh orang lain kepada kita disebut dengan dukungan sosial (Sarason dkk., 1996). Menurut Morish (dalam Ahmadi \& Supriyono, 2004) teman sebaya adalah kelompok yang didalamnya terdapat individu yang sama, baik dalam hal status sosial, usia, lingkungan, tanggung jawab dan juga dapat berupa teman sepermainan. Secara keseluruhan, Gartner dan Riessman (Solomon, 2004) mendefinisikan dukungan teman sebaya adalah support baik dari segi emosi maupun sosial yang diberikan oleh seseorang dengan kriteria yang sama hingga menjadi individu dengan kepribadian lebih baik juga diinginkan.

Jika dukungan sosial teman sebaya yang diberikan semakin banyak maka semakin baik pula penerimaan dirinya. Sebaliknya, jika dukungan sosial teman sebaya yang diberikan semakin rendah maka penerimaan dirinya semakin buruk. Dukungan sosial yang diberikan oleh teman sebaya terbagi dalam 3 bentuk, yaitu: (a) dukungan secara emosi, adalah dukungan dari seseorang untuk memberi simpati, rasa sayang, kehangatan, dan juga perhatian, dukungan informasi, yaitu dukungan dengan cara memberi informasi, nasihat, ataupun sugesti (Sarafino \& Smith, 2011). Satu lagi yaitu dukungan konkret, adalah dukungan dengan maksud memberi bantuan yang nyata dan terlihat oleh mata contohnya meminjami uang atau hal lain kepada orang (Tracy dalam Corcoran \& Roberts, 2015). Penelitian ini menjadi pendukung penelitian terdahulu yang mengatakan bahwa ada hubungan antara dukungan sosial yang diberikan teman sebaya terhadap penerimaan diri (Ridha, 2012). Seseorang yang memiliki citra tubuh yang baik, maka dia akan menerima kelebihan dan kekurangannya dengan percaya diri (Hasmalawati, 2017).

\section{Kesimpulan dan Saran}

Hasil penelitian menunjukkan adanya hubungan yang positif dan signifikan antara citra tubuh dan dukungan teman sebaya dengan penerimaan diri pada ODO (Orang dengan Obesitas). Seseorang yang mempunyai citra tubuh yang baik maka akan mempunyai penerimaan diri yang baik pula. Begitupun sebaliknya, seseorang yang mempunyai citra tubuh yang buruk maka penerimaan dirinya 
akan rendah. Dukungan sosial teman sebaya yang diberikan semakin tinggi maka penerimaan dirinya semakin baik, begitupun sebaliknya.

Penelitian ini dirasa banyak keterbatasan dan kekurangan antara lain (1) jumlah responden hanya 100 orang, hal ini tentu masih kurang untuk menggambarakan keadaan yang sesungguhnya, (2) subjek penelitian ini hanya terfokus pada media sosial twitter, padahal masih banyak media sosial lainnya seperti Instagram, Facebook, dll. Namun semoga penelitian ini bisa dijadikan sumber referensi bagi penilitian-penelitian selanjutnya. Saran dalam penelitian ini yaitu bagi orang-orang yang mempunyai kerabat mengalami ODO maka diharapkan untuk memberi dukungan karena hal ini sangat berarti bagi orang dengan obesitas.

\section{Daftar Pustaka}

Ahmadi, A., \& Supriyono, W. (2004). Psikologi Belajar. PT Rineka Cipta.

Andarbeni, L., \& Probosari, E. (2019). Perbedaan Kadar Asam Urat Pada Wanita Lansia Dengan Persen Lemak Tubuh Obesitas Dan Non-Obesitas. Journal of Nutrition College, 8 (4), 231-237. https://doi.org/10.14710/jnc.v8i4.25836

Aquino, M. T., Orense, C. L., Tanchoco, C. C., Amarra, S. V., Tajan, M. G., \& Cruz, E. O. D. (2009). Correlates of Body Image Satisfaction Among Economically Depressed Urban Filipino Women. Philippine Journal of Science, 138(1), 67-74.

Brennan, M. A., Lalonde, C. E., \& Bain, J. L. (2010). Body Image Perceptions: Do Gender Differences Exist? Psi Chi Journal of Undergraduate Research, 15(3).

Cash, T. F. (2004). Editorial Body Image: Past, Present, and Future. Citra tubuh: an International Journal of Research, 1(1), 1-5.

Chaplin, J. P. (1999). Kamus Lengkap Psikologi. PT Raja Grafindo Persada.

Corcoran, K., \& Roberts, A. R. (2015). Social Workers Desk Reference. Oxford University Press.

Devaraj, S., \& Lewis, V. (2010). Enhancing Positive Body Image in Women: An Evaluation of a Group Intervention Program. Journal of Applied Biobehavioral Research, 15(2), 103-116.

Fernando, M. L. (2019). Gambaran Body Image Pada Wanita Dewasa Awal Yang Mengalami Obesitas. Jurnal Ilmiah Psikologi Terapan (JIPT), 7 (1). https://doi.org/10.22219/jipt.v7i1.6369

Gillen, M. M., \& Lefkowitz, E. S. (2011). Body Size Perceptions in Racially/Ethnically. North American Journal of Psychology, 13(3), 447-468.

Gibney, M. (2008). Gizi Kesehatan Masyarakat. EGC.

Grogan, S. (1999). Body Image: Understanding Body Dissatisfaction in Men, Women, and Children. Routledge.

Handayani, M. M., Ratnawati, S., \& Helmi, A. F. (1998). Efektifitas Pelatihan Pengenalan Diri Terhadap Peningkatan Penerimaan Diri dan Harga Diri. JURNAL PSIKOLOGI, 25(2), 47-55. https://doi.org/10.22146/jpsi.7504 
Citra Tubuh, Dukungan Sosial Teman Sebaya, dan Penerimaan Diri pada Orang Dengan Obesitas (Odo) Proyeksi, Vol. 16 (2) 2021, 198-207

Hasmalawati, N. (2017). Pengaruh Body Image Dan Perilaku Makan Terhadap Penerimaan Diri Pada Wanita. Jurnal Psikois/amedia, 2 (2). http://dx.doi.org/10.22373/psikoislamedia.v2i2.1892

Heatherton, T. F. (1993). Body Dissatisfaction, Self-Focus, and Dieting Status Among Women. Psychology of Addictive Behaviors, 7(4), 225-231.

Hendra, C., Manampiring, A. E., \& Budiarso, F. (2016). Faktor-Faktor Risiko terhadap Obesitas pada Remaja di Kota Bitung. Jurnal e-Biomedik (eBm), 4 (1). https://doi.org/10.35790/ebm.4.1.2016.11040

Heriyadi, A. (2013). Meningkatkan Penerimaan Diri (Self Acceptance) Siswa Kelas VIII Melalui Konseling Realita di SMP Negeri 1 Bantarbolang Kabupaten Pemalang Tahun Ajaran 2012/2013 [Universitas Negeri Semarang]. https://lib.unnes.ac.id/17348/1/1301406027.pdf

Hjelle, L. A., \& Zeigler, D. J. (1992). Personality Theories: Basic Assumptions, ResearchAnd Application. MC Graw Hill.

Hurlock, E. B. (1999). Psikologi Perkembangan: Suatu Pendekatan Sepanjang Rentang Kehidupan. Erlangga.

Indonesia, K. K. R. (2008). Riset Kesehatan Dasar Tahun 2007. Badan Penelitian dan Pengembangan Kesehatan, Kementerian Kesehatan.

Maryam, S., \& Ifdil. (2019). Hubungan Body Image Dengan Penerimaan Diri Mahasiswa Putri (Relationship Between Citra tubuh And Self-Acceptance Of Female Students). Jaiptrkin, 3(3).

Nadimin, Ayumar, \& Fajarwati. (2015). Obesitas pada Orang Dewasa Anggota Keluarga Miskin di Kecamatan Lembang Kabupaten Pinrang. Media Kesehatan Masyarakat Indonesia: The Indonesian Journal of Public Health, 11 (3).

P2PTM, K. R. (2018). Klasifikasi Obesitas Setelah Pengukuran IMT. Kementerian Kesehatan Republik Indonesia. http://p2ptm.kemkes.go.id/infographic-p2ptm/obesitas/klasifikasi-obesitassetelah-pengukuran-imt

Ridha, M. (2012). Hubungan Antara Body Image Dengan Penerimaan Diri Pada Mahasiswa Aceh Di Yogyakarta. EMPATHY, 1 (1).

Safitri, D. E., \& Rahayu, N. S. (2020). Determinan Status Gizi Obesitas pada Orang Dewasa di Perkotaan: Tinjauan Sistematis. ARKESMAS, 5 (1). https://doi.org/10.22236/arkesmas.v5i1.4853

Sarafino, E. P., \& Smith, T. W. (2011). Health Psychology: Biopsychology Interactions. John Wiley \& Sons.

Sarason, B. R., Pierce, G. R., \& Sarason, I. G. (1996). Handbook of Social Support and the Family. Plenum Press.

Sarwer, D. B., Thompson, J. K., \& Cash, T. F. (2005). Body Image and Obesity in Adulthood. The Psychiatric Clinics of North America, 8(1), 69-87. 
Novi Nindy Elisa, Lina Nur Elfiana, Delvina Alifah Rahma, dan Abdul Muhid

Sarwono. 2011. Psikologi Remaja.Edisi Revisi. Jakarta: Rajawali Pers.

Sawitri, M., Anggraini, Y., \& Sari, S. M. (2019). Faktor Faktor yang Berhubungan Dengan Obesitas Pada Remaja di SMPN 1 Ujungbatu. JOMIS (Journal Of Midwifery Science), 3 (2).

Situmorang, M. (2015). Penentuan Indeks Massa Tubuh (IMT) melalui Pengukuran Berat dan Tinggi Badan Berbasis MikrokontrolerAT89S51 dan PC. Jurnal Teori dan Aplikasi Fisika, 3 (2). http://dx.doi.org/10.23960\%2Fjtaf.v3i2.1291

Solomon, P. (2004). Peer Support/Peer Provided Services Underlying Processes, Benefits, and Critical Ingredients. Psychiatric Rehabilitation Journal, 27(4), 392-401.

Sundari, L. P. R. (2018). Defisiensi Vitamin D Pada Obesitas. Sport and Fitness Journal, 6 (1), 1-5. https://doi.org/10.24843/spj.2018.v06.i01.p01

Supratiknya, A. (1995). Komunikasi Antarpribadi: Tinjauan Psikologis. Kanisius.

Vizza, N., \& Ningsih, Y. (2019). Kontribusi Dukungan Sosial Teman Sebaya Terhadap Penerimaan Diri Remaja Yatim Atau Piatu Di Panti Asuhan. Jurnal Riset Psikologi, Volume 2019(3). http://dx.doi.org/10.24036/jrp.v2019i3.6881

Widianti, W., \& Tafal, Z. (2014). Aktivitas Fisik, Stres, dan Obesitas pada Pegawai Negeri Sipil. Pusat Data Dan Informasi Sekretariat Jenderal Kementerian Kesehatan Republik Indonesia, 8(7), 330336. 